\title{
Erratum zu: Interdisziplinarität im Entwurf
}

\section{Zur Geschichte einer Denkform des Erkennens in der Bundesrepublik (1955-1975)}

\section{Susanne Schregel}

Erratum to: Drafting Interdisciplinarity. Forms of Thought and Knowledge Production in the Federal Republic of Germany (1955-1975)

\section{Erratum zu: N.T.M.}

\section{DOI 10.1007/s00048-016-0138-3}

In der Online-Version des Originalartikels wurde der englische Titel direkt hinter den deutschen Titel gestellt. Der korrekte Titel des Beitrags lautet:

Interdisziplinarität im Entwurf. Zur Geschichte einer Denkform des Erkennens in der Bundesrepublik (1955-1975)

Der Originalbeitrag ist inzwischen korrigiert.

\section{Susanne Schregel}

The Institute for Advanced Studies in the

Humanities (IASH)

The University of Edinburgh

Hope Park Square

Edinburgh EH8 9NW

Scotland, UK

Die Online-Version des Originalartikels können Sie unter doi:10.1007/s00048-016-0138-3 finden. 
a.r.t.e.s. Graduate School for the Humanities

Cologne

Research Lab

Research Group "Transformations of Knowledge”

Universität zu Köln

Albertus-Magnus-Platz Cologne

Germany

E-Mail:s.schregel@uni-koeln.de 